\title{
Impact of Insecticide, Chlorpyrifos on Protein and Amino Acid Contents in Liver, Kidney and Brain of Exotic Teleost Fish, Channa punctatus (Bloch, 1973)
}

\author{
Revathi B', Lakshmanan $\mathrm{S}^{2, *}$, Veerakumar $\mathrm{D}^{3}$
}

Revathi $\mathrm{B}^{1}$, Lakshmanan $\mathrm{S}^{2, *}$, Veerakumar $\mathrm{D}^{3}$

'Ph.D, Research Scholar, Department of Zoology, Poompuhar College (Autonomous), Melaiyur - 609 107, Sirkali Taluk,

Nagapattinam, Tamilnadu, INDIA.

${ }^{2}$ Assistant Professor, Department of Zoology,

Poompuhar College (Autonomous), Melaiyur

- 609 107, Sirkali Taluk, Nagapattinam, Tamilnadu, INDIA

${ }^{3} P h . D$, Research Scholar, Department of

Zoology, Annamalai University, Annamalai

Nagar- 608 002, Tamilnadu, INDIA.

\section{Correspondence}

\section{Lakshmanan S}

Assistant Professor, Department of Zoology, Poompuhar College (Autonomous), Melaiyur - 609 107, Sirkali Taluk, Nagapattinam. Tamilnadu, INDIA. E-mail: mirsahil32653@gmail.com

History

- Submission Date: 26-11-2019;

- Review completed: 19-12-2019;

- Accepted Date: 09-01-2020.

DOI : 10.5530/pj.2020.12.55

Article Available online

http://www.phcogj.com/v12/i2

Copyright

(C) 2020 Phcogj.Com. This is an openaccess article distributed under the terms of the Creative Commons Attribution 4.0 International license.

\begin{abstract}
Pesticides are one of the most potentially harmful toxic chemicals introduced into the environment and human ambient. These pesticides are utilized widely to ensure agricultural harvests against the harm brought about by different sorts of irritations. Anyway, these chemicals may reach non focused on biological systems like lakes and waterways through rain and wind, influencing numerous different organisms. Biochemical factors show explicit reactions to specific types of ecological pressure. The methodology of present work was to assess toxic effects of an insecticide, chlorpyrifos on biochemical constituents like protein, and Amino acid in liver, kidney and Brain of freshwater fish, Channa punctatus. The fish exposed to chlorpyrifos showed a decrease the protein and increase the amino acid levels for 15 and 45 days in liver, kidney and brain compared to control. The objectives of the present work was to observe the effect of chlorpyrifos on protein and amino acid levels in the liver, kidney and brain of teleost fish Channa punctatus.
\end{abstract}

Key words: Chlorpyrifos, Biochemical constituents, Liver, Kidney, Brain, Channa punctatus.

\section{INTRODUCTION}

Pollution problem is currently encountered everywhere the globe, with a rise in manufacture, urbanization, surplus use of agrochemicals like pesticides, herbicides, fungicides etc. To enhance yield of agricultural merchandise. Among the various kinds of pesticides, organophosphates have gotten one of the generally utilized classes of pesticides. The impacts of introduction of aquatic environment to these pesticides are hard to survey in light of their short steady in water section because of low solvency and quick debasement. Hence, monitoring of these insecticides is important. ${ }^{1,2}$

Occupational exposure to pesticides is a common and alarming worldwide phenomenon. Around, 3 million instances of intense harming and 0.22 million passings from pesticide presentation have been accounted for yearly. ${ }^{3-6}$ In India, pesticides set up a critical section in cultivating headway and affirmation of general prosperity since the tropical environment is useful for bothering reproducing.

Contamination by pesticides in aquatic ecosystem is a serious problem and fishes are more frequently exposed to these pollutants and may be taken in through gills, skin and contaminated foods. ${ }^{8}$ Fish are broadly used to assess the strength of aquatic biological systems since poisons develop in the natural pecking order and are liable for unfriendly impacts and demise in the sea-going frameworks. ${ }^{9}$

Synthetic Organophosphates [OP] Chlorpyrifos $[\mathrm{CPF}]$ is a pharmaceutical product, widely used to control various pests of agriculture and veterinary for public health protection..$^{10}$ According to a recent report, children exposed to chlorpyrifos while in the womb have an increased risk of delays in mental and motor development at age 3 and an increased occurrence attention-deficit hyperactivity disorder. ${ }^{11}$ There are some reports shows toxic potentials of OP pesticides on tadpoles. ${ }^{12}$

Chlorpyrifos (O, O-diethyl-O-3, 5, 6-trichlor2pyridyl phosphorothioate; CPF) (Figure 1) is a wide range organophosphate bug spray (OP) which is industrially utilized for over 10 years to control creepy crawly bug. Chemical formulla $\mathrm{C}_{9} \mathrm{H}_{11} \mathrm{C}_{13} \mathrm{NO}_{3} \mathrm{PS}$. Since, it was first introduced into the market place in 1965. It is the second biggest selling OP and saw as more lethal to angle than organochlorine compounds. CPF passes through air float or surface spillover into regular waters, where it is collected in various life forms living in water, particularly in fish, consequently making it powerless against a few noticeable impacts. $\mathrm{CPF}$ is known to inhibit acetylcholinesterase, cause behavioural, neurological, oxidative, histopathological, endocrine and other effects at low doses. CPF is also known by its trade names Dursban and Lorsban. ${ }^{13}$

$\mathrm{CPF}$ (Chlorpyrifos) is also widely used in agriculture as the substitutes for methamidophos and parathion in China, and has become one of the major pesticides detected in farm products. ${ }^{14,15}$ Since farming uses

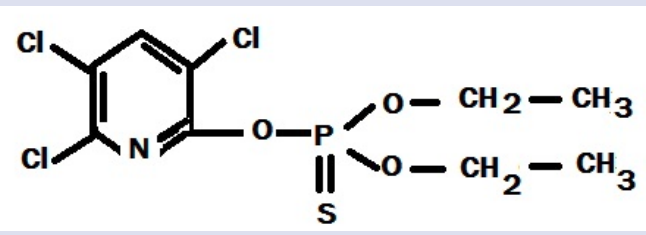

Figure 1: Structure of Chlorpyrifos.

Cite this article: Oktaviono $\mathrm{YH}$, Amadis MR, Al-Farabi MJ. High Dose Allicin with Vitamin C Improves EPCs Migration from the Patient with Coronary Artery Disease. Pharmacog J 2020;12(2):351-5. 
on plantations and column crops persevere, CPF has been every now and again identified in air, nourishment and water. Although various standards exist to minimize its exposure in food and water, CPF is frequently used and bio-accumulates in certain scenarios. ${ }^{16,17}$ Fish are presumably the most significant non-target casualties of pesticide over presentation as they have a significant job in natural way of life.

The present study, above the reports on the effects of low dose of Chlorpyrifos in fresh water teleost fish Channa punctatus are still scanty. In the light of above information and ideas, present investigation is aimed to study the effect of Chlorpyrifos on liver kidney and brain of the fresh water teleost fish Channa punctatus.

\section{MATERIALS AND METHODS}

\section{Procurement of test fish}

The fresh water fish, Channa punctatus were collected from kollidam river around sirkali city with the help of fisherman. The fishes having average length $13-16 \mathrm{~cm}$ and weight about 20-25 gm were brought to the laboratory and transferred to aerated aquarium for acclimatization. The fishes were fed daily on commercial fish feed.

\section{Pesticide}

Organophosphate pesticide chlorpyrifos purchased from local agro chemist shop was used for the present study.

\section{Plan of experiment}

A total of 40 fishes (10 fishes per aquarium) were separated as four groups.

The following experimental groups were conducted in the freshwater fish Channa punctatus for the period of 45 days.

- Group 1 C. punctatus, without any pesticide exposure (control)

- Group 2 C. punctatus, on exposure to 5 ppm chlorpyrifos for a period of 15 and 45 days

- Group 3 C. punctatus, on exposure to $6 \mathrm{ppm}$ chlorpyrifos for a period of 15 and 45 days

- Group 4 C. punctatus, on exposure to 7 ppm chlorpyrifos for a period of 15 and 45 days

\section{Biochemical methods}

The protein and amino acid content in Liver, kidney and brain of Channa punctatus were estimated by the method of Lowry et al., 1951 and Moore and Stein (1954) respectively. ${ }^{18,19}$

\section{STATISTICAL ANALYSIS}

The data obtained were analyzed by applying analysis of variance DMRT one way ANOVA to test the level of significance. ${ }^{20}$

\section{RESULT}

The protein and amino acid contents in Liver, kidney and brain of Channa punctatus exposed to low, medium and high sublethal concentrations of chlorpyrifos showed significant decrease in the level of protein whereas increase the levels of amino acids when compared to control fish. The decrease the level of protein and increase the level of amino acid in liver, kidney and brain of Channa punctatus were more pronounced at 15 and 45 days of exposure period (Tables 1 and 2).

\section{DISCUSSION}

Various aquatic scavangers have been utilized to assess ecotoxicological dangers; nonetheless, little data about them by and by contemplated
Table 1: Protein level changes $(\mathrm{mg} / \mathrm{g}$ ) in Liver, kidney and brain of Channa punctatus exposed to sublethal concentrations of chloryrifos.

\begin{tabular}{lcc}
\hline Treatment groups & 15 days & 45 days \\
\hline Liver & $141.39 \pm 1.67^{\mathrm{a}}$ & $142.78 \pm 2.85^{\mathrm{a}}$ \\
Control & $136.94 \pm 4.62^{\mathrm{b}}$ & $134.84 \pm 1.49^{\mathrm{b}}$ \\
Low concentration & $128.52 \pm 8.27^{\mathrm{c}}$ & $125.76 \pm 2.75^{\mathrm{c}}$ \\
Medium concentration & $120.92 \pm 7.30^{\mathrm{d}}$ & $117.53 \pm 1.56^{\mathrm{d}}$ \\
High concentration & & \\
Kidney & $92.39 \pm 2.67^{\mathrm{a}}$ & $93.67 \pm 2.49^{\mathrm{a}}$ \\
Control & $84.75 \pm 6.39^{\mathrm{b}}$ & $83.57 \pm 1.84^{\mathrm{b}}$ \\
Low concentration & $76.36 \pm 9.47^{\mathrm{c}}$ & $72.64 \pm 1.59^{\mathrm{c}}$ \\
Medium concentration & $68.58 \pm 7.89^{\mathrm{d}}$ & $70.93 \pm 2.50^{\mathrm{d}}$ \\
High concentration & & \\
Brain & $87.39 \pm 2.98^{\mathrm{a}}$ & $88.98 \pm 1.47^{\mathrm{a}}$ \\
Control & $81.48 \pm 8.45^{\mathrm{b}}$ & $79.48 \pm 1.39^{\mathrm{b}}$ \\
Low concentration & $74.69 \pm 7.25^{\mathrm{c}}$ & $72.85 \pm 2.05^{\mathrm{c}}$ \\
Medium concentration & $68.31 \pm 4.62^{\mathrm{d}}$ & $63.65 \pm 1.83^{\mathrm{d}}$ \\
\hline High concentration &
\end{tabular}

All the values mean SD of six observations;Values which are not sharing common superscript differ significantly at 5\% $(p<0.05)$ [Duncan multiple range test (DMRT).

Table 2: Amino acid ( $\mathrm{mg} / \mathrm{g}$ ) in Liver, kidney and brain of Channa punctatus exposed to sublethal concentrations of chloryrifos.

\begin{tabular}{lcc}
\hline Treatment groups & 15 days & 45 days \\
\hline Liver & $7.03 \pm 0.29^{\mathrm{a}}$ & $7.78 \pm 0.32^{\mathrm{a}}$ \\
Control & $7.98 \pm 0.47^{\mathrm{b}}$ & $8.02 \pm 0.24^{\mathrm{ab}}$ \\
Low concentration & $8.38 \pm 0.18^{\mathrm{bc}}$ & $8.67 \pm 0.32^{\mathrm{c}}$ \\
Medium concentration & $9.42 \pm 0.57^{\mathrm{d}}$ & $9.84 \pm 0.54^{\mathrm{d}}$ \\
High concentration & & \\
Kidney & $4.29 \pm 0.19^{\mathrm{a}}$ & $4.37 \pm 0.38^{\mathrm{a}}$ \\
Control & $4.88 \pm 0.38^{\mathrm{b}}$ & $4.92 \pm 0.10^{\mathrm{b}}$ \\
Low concentration & $5.59 \pm 0.31^{\mathrm{c}}$ & $5.89 \pm 0.39^{\mathrm{c}}$ \\
Medium concentration & $6.32 \pm 0.19^{\mathrm{d}}$ & $7.14 \pm 0.42^{\mathrm{d}}$ \\
High concentration & & \\
Brain & $3.67 \pm 0.28^{\mathrm{a}}$ & $3.89 \pm 0.29^{\mathrm{a}}$ \\
Control & $3.98 \pm 0.36^{\mathrm{b}}$ & $4.02 \pm 0.21^{\mathrm{ab}}$ \\
Low concentration & $4.67 \pm 0.48^{\mathrm{c}}$ & $4.98 \pm 0.54^{\mathrm{c}}$ \\
Medium concentration & $5.10 \pm 0.27^{\mathrm{d}}$ & $5.67 \pm 0.37^{\mathrm{d}}$ \\
\hline High concentration &
\end{tabular}

All the values mean SD of six observations;Values which are not sharing common superscript differ significantly at $5 \%(p<0.05)$ [Duncan multiple range test (DMRT)

bug sprays have been accounted for in these creatures. In such a manner to intense poisonous quality testing, different pesticides have been contemplated. Permethrin, for instance, demonstrated a mean static intense $96-\mathrm{h} \mathrm{LC}_{50}$ relating to $0.81 \mathrm{mg} / \mathrm{L}$ in red bog crawfish Procambarus clarkii; in a similar creature, a differentiating LC $_{50}$ estimation of 951 $\mathrm{mg} / \mathrm{L}$ was resolved for the bug spray chlorantraniliprole, while for the neonicotinoids mixes thiametoxan and dinotefuran, creators detailed estimations of $967 \mathrm{~m} / \mathrm{L}$ and $2032 \mathrm{mg} / \mathrm{L}$, separately; which are altogether different from the saw in the pyrethroids clotianidin, lambdacyhalothrin, and etofenprox: 59, 0.16 and $0.29 \mathrm{mg} / \mathrm{L}$, individually. ${ }^{21-23}$

Chlorpyrifos poisonous quality has been the subject of numerous toxicological examinations, and much information has been accumulated up to this point, indicating its principle components of activity and different unfavorable impacts, both in creatures and people. Nonetheless, what has not been replied at this point, and our investigation attempted to clarify, is whether a rehashed 15 and 45 day presentation to low, medium and High "practical" convergences of chlorpyrifos produce any indications of inebriation. Our outcomes 
could reveal new insight into chlorpyrifos' harmfulness profile and add new discoveries important to human hazard appraisal.

Fish represents the higher tropic level in the amphibian natural pecking order. Hence, the steadiness of lethal compound amasses to the most extreme fixation in their body when contrasted with dissimilar living beings in the sea-going condition. ${ }^{24}$ Fish is generally devoured in numerous pieces of the world since it has high protein content, low soaked fat and furthermore contains omega unsaturated fats known to help great wellbeing. ${ }^{25}$ Proteins are significant natural substances vital for living beings in tissue building and assume a critical job in energy metabolism. ${ }^{26}$

The kidney, which is an important organ of excretion and osmoregulation, is indirectly affected by pollutants through blood circulation..$^{27}$ The brain is highly vulnerable to oxidative stress due to its high metabolic rate, the reduced capacity for cellular regeneration, and numerous cellular oxidative stress targets like lipids, nucleic acids, and proteins. Generally, most molecules cannot cross the blood-brain barrier (BBB). But, due to large surface area, the NPs made of certain materials and with varying particle sizes can overcome this physical barrier and enter into the brain. ${ }^{28}$

Pesticides can make genuine disability the physiological and wellbeing status of fish. Accordingly, biochemical tests are normal research center tests valuable in perceiving intense or constant harmfulness of bug sprays and can be a commonsense device to analyze danger impacts in target organs and to decide the physiological status in fish. Chlorpyrifos prompted biochemical adjustments in fish detailed by different analysts proposed they are great parameters that help to see the impacts of toxicants on the digestion of fish..$^{29,30}$

In the present investigation freshwater fish, Channa punctatus exposed to sublethal concentrations of chloryrifos for the periods of 15 and 45 days shows decrease the levels of protein and elevated levels of amino acid in liver, kidney and brain. The present work agrees with Tulasi and Jayantha Rao (2013) ${ }^{31}$ addressed that total protein content is decreased and it may be due to breakdown of proteins in the fabrication of some amount of energy for organism.

In an organism toxic substances brings about a kind of stress and an organism responds to that by developing necessary potential. During stress, organism needs sufficient energy which is supplied from reserve food material i.e. protein, glycogen and lipid. ${ }^{32}$ Protein plays a crucial role in virtually all biological processes. Under extreme stress, protein supply energy in metabolic pathways and biochemical reactions. ${ }^{33}$ Decrease in protein might be due to the impairment of protein synthesis or increase in the rate of it's degradation to amino acid. This might be fed to TCA cycle aminotransferase to cope with high energy demands to meet the stress condition. Decreased protein content observed in the present investigation was might be due to these reasons.

Lakshmanan et al. $(2013)^{34}$ examined the significant reduced in glycogen, protein and albumin in fish Oreochromis mossambicus during treatment of dichlorvos. Nagraju and Venkata Rathnamma $(2013)^{35}$ researched the effect of profenofos and carbosulphan on biochemical characteristics of the fresh water fish Labeo rohita and reported decreased glycogen content in gill, liver, kidney, brain and muscle.

Padmini and Rajaram (2016) ${ }^{36}$ addressed the effect of different concentrations of chlorpyrifos viz. 0.04, 0.045, 0.05, 0.055, 0.06 and $0.065 \mathrm{ml} / \mathrm{L}$ on protein, glycogen and lipid in liver and kidney of Channa gachua for $96 \mathrm{~h}$ and reported decreased levels in both the tissues in comparison with control. The decreased protein and increased amino acid contents in the gill, liver, kidney, heart and muscle of Catla catla exposed to cadmium chloride. ${ }^{37}$
Reddy et al. (2011) ${ }^{38}$ studied the effect of sublethal concentrations of chlorpyrifos on protein metabolism in gills, kidney, liver, and muscle of Clarias batrachus exposed to $0.825 \mathrm{mg} / \mathrm{L}$ and $1.65 \mathrm{mg} / \mathrm{L}$ for 7,14 , 21 , and 28 days. Total protein, amino acid, and ammonia contents were decreased in all tissues for 28 days. Urea and glutamine levels were elevated, except in kidneys. The activities of protease, alanine, and aspartate aminotransferases, and acid and alkaline phosphatises were elevated in the tissues for 28 days exposure at both concentrations.

It is apparent that proteins are corrupted to meet the vitality prerequisites during pesticide CPF presentation. It very well may be reasoned that in Channa punctatus presented to sublethal groupings of Chlorpyrifos causes vitality emergency and change protein digestion.

\section{CONCLUSION}

In view of higher than results and discussion, gift study showed organophosphate treated fishes changes in macromolecule, and organic compound content in bony fish of Channa puntatus, that indicates organic chemistry manifestation great to the toxic action of toxicants. Toxic induces its impact at cellular or maybe at molecular level and ultimately causes organic chemistry alterations. The changes in organic chemistry composition of fishes can naturally have an effect on the nutritious price of aquatic fauna and deteriorating the worth of fish and itll conjointly nice danger to individual great to continuous consumption of such fish.

\section{ACKNOWLEDGMENT}

The authors are grateful to the Principal, Poompuhar College (Autonomous), Poompuhar College (Autonomous) and Dr. J. Gokulakrishnan, Assistant Professor and Head of the Department of Zoology, Poompuhar College (Autonomous), Tamilnadu, India for providing various facilities in connection with this research work.

\section{REFERENCES}

1. Chebbi SG, David M. Respiratory responses and behavioural anomelies of the carp Cyprinus carpio under qinalthos intoxication in sublethal doses. Science Asia. 2010;36:12-7

2. Subburaj A, Jawahar P, Jayakumar N, Srinivasan A, Ahilan B. Acute toxicity bioassay of Malathion (EC $50 \%$ ) on the fish Oreochromis mossambicus (Tilapia) and associated histological alterations in gills. Journal of Entomology and Zoology Studies. 2018;6(1):103-7

3. Marrs TC. Organophosphate poisoning. Pharmacol Ther. 1993;58:51-66

4. USDA. Agriculture Chemical Usage Field Crop Study. US Department of Agriculture, Washington, DC, 1994;396-432

5. Yasmashita M, Tanaka J, Ando Y. Human mortality in organophosphate poisonings. Vet Hum Toxicol. 1997:39:84-5.

6. Ali D, Nagpure NS, Kumar S, Kumar R, Kushwaha B, Lakra WS. Assessment of genotoxic and mutagenic effects of chlorpyrifos in freshwater fish Channa punctatus (Bloch) using micronucleus assay and alkaline single-cell gel electrophoresis. Food and Chemical Toxicology. 2009;47(3):650-6.

7. Kumar M, Prasad MR, Srivastva K, Tripathi S, Srivastva AK. Branchial histopathological study of Catfish Heteropneustes fossilis following exposure to purified neem extract, Azadirachtin. World Journal of Zoology. 2010:5(4):23943.

8. Ling $X P$, Zhang $Y H$, Lu YH, Huang $H Q$. Superoxide dismutase, catalase and acetyl cholinesterase: biomarkers for the joint effects of cadmium, zinc and methyl parathion contamination in water. Environmental Technology. 2011;32(13):1463-70

9. Farkas A, Salanki J, Specziar A. Relation between growth and the heavy metal concentration in organs of bream Abramis brama L populating Lake Balaton. Archives of Environmental Contamination and Toxicology. 2002;43(2):236-43.

10. Singh BK, Walker A. Microbial degradation of organophosphorus compounds FEMS Microbiol Rev. 2006;30:428-71

11. Rauh VA, Garfinkel R, Perera FP, Andrews HF, Hoepner L, Barr DB, et al. Impact of prenatal chlorpyrifos exposure on neurodevelopment in the first 3 years of life among inner-city children. Pediatrics. 2006;118:1845-59. 
Revathi B, et al.: Impact of Insecticide, Chlorpyrifos on Protein and Amino Acid Contents in Liver, Kidney and Brain of Exotic Teleost Fish, Channa punctatus (Bloch, 1973)

12. Li X, Li S, Liu S, Zhu G. Lethal effect and in vivo genotoxicity of profenofos to Chinese native amphibian (Rana spinosa) tadpoles. Arch Environ Con Toxicol. 2010;59:478-83.

13. Deb N, Das S. Chlorpyrifos toxicity in fish: a review. Current World Environment. 2013;8(1):77

14. Chen C, Li Y, Chen M, Chen Z, Qian Y. Organophosphorus pesticide residues in milled rice (Oryza sativa) on the Chinese market and dietary risk assessment. Food Addit Contam Part A Chem Anal Control Expo Risk Assess. 2009;26:340-7.

15. Sun F, Chen HS. Monitoring of pesticide chlorpyrifos residue in farmedish: investigation of possible sources. Chemosphere. 2008;71:1866-9

16. Varó I, Serrano R, Pitarch E, Amat F, López FJ, Navarro JC. Bioaccumulation of chlorpyrifos through an experimental food chain: study of protein HSP7O as biomarker of sublethal stress in fish. Arch Environ Contam Toxicol. 2002;42:229-35.

17. Jantunen AP, Tuikka A, Akkanen J, Kukkonen JV. Bioaccumulation of atrazine and chlorpyrifos to Lumbriculus variegates from lake sediments. Ecotoxicol Environ Saf. 2008:71:860-8.

18. Lowry $\mathrm{OH}$, Rosenbrough NJ, Farr AL, Randall RJ. Protein measurement with the Folin -phenol reagent. J Biol Chem. 1951;193:265-73

19. Moore S, Stein WH. A modified ninhydrin reagent for the photometric determination of amino acid and related compounds. J Biol Chem. 1954:211:907-13

20. Duncan BD. Multiple range test for correlated and heteroscedastic means. Biometrics. 1957;13:359-64.

21. Jarboe HH, Romaire RP. Acute toxicity of permethrin to four size classes of red swamp crayfish (Procambarus clarkia) and observations of postexposure effects. Archives of Environmental Contamination and Toxicology. 1991;20:337-42.

22. Barbee GC, Stout MJ. Comparative acute toxicity of neonicotinoid and pyrethroid insecticides to non-target crayfish (Procambarus clarkii) associated with rice-crayfish crop rotations. Pest Management Science. 2009:65:1250-6.

23. Barbee GC, McClain WR, Lanka SK, Stout MJ. Acute toxicity of chrorantraniliprole to nontarget crayfish (Procambarus clatkil) associated with rice-crayfish cropping systems. Pest Management Science. 2010;66:996-1001.

24. Sackmauerova MO, Palusova A, Szokolay, Uhnak J. Dynamics of the residues of chlorinated pesticides in the biocenose of the Danube River. Agrochemia. 1977; $17: 46-8$.

25. Ikem A, Egiebor NO. Assessment of trace elements in canned fishes (Mackerel, Tuna, Salmon, Sardines and Herrings) marketed in Georgia and Alabama (United States of America). J Food Comp Anal. 2005;18:771-87.
26. Al-Kahtani MA. Effect of an insecticide abamectin on some biochemical characteristics of tilapia fish (Oreochromis Niloticus). Am J Agrl Biol Sci. $2011 \cdot 6 \cdot 62-8$

27. Newman MW, MacLean. Physiological response of the cunner Tautogoloborous adspersus to cadmium VI: Histopathology No. A Tech. Report, NMFS, SSRF $1974 ; 681$

28. Palaniappan PLRM, Pramod KS. The effect of titanium dioxide on the biochemical constituents of the brain of Zebrafish (Danio rerio): An FT-IR study. Spectrochimica Acta Part A. 2011;79:206-12.

29. Banaee M, Mirvaghefi AR, Ahmadi K, Banaee S. Determination of $L_{50}$ and investigation of acute toxicity effects of diazinon on haematology and serology indices of common carp (Cyprinus carpio). Journal of Marine Science and Technology Research. 2008;3(2):1-10.

30. Kajare A, Singh S, Shrivastava K. Malathion induced biochemical changes in kidney of freshwater fish Clarias batrachus. Ecotoxicology and Environmental Monitoring. 2000;10:11-4.

31. Tulasi G, Jayantha Rao K. Effect of chromium on protein metabolisam in different tissues of fish, Cyprinus carpio. Research Journal of Pharmaceutical, Biological and Chemical Sciences. 2013;4(1):143-8

32. Hyalii MT. Effect of sugar factory effluent on glycogen, protein and free amino acid content in tissue of the fish Lepidocephalus thermalis. Journal of Environmental Research and Development. 2013;7(3):1228-30.

33. Ganeshwade RM. Biochemical changes induced by dimethote in the liver of fresh water fish Punctius ticto (Ham). Biological forum an Int J. 2011;3(2):65-8.

34. Lakshmanan SA, Rajendran C. Sivasubramaniyan. Impact of dichlorvos on tissue glycogen and protein content in freshwater fingerlings, Oreochromis mossambicus (Peters). Int J Res Environ Sci Technol. 2013;3(1):19-25.

35. Nagaraju B, Venkata Rathnamma V. Effect of two pesticides on some biochemical characteristics of the fresh water fish Labeo rohita (Hamilton). Journal of Biology and Today's World. 2013:2(9):425-41.

36. Padmini K, Rajaram P. Effect of chlorpyrifos on some biochemical constituents in liver and kidney of freshwater fish, Channa gachua (F. Hamilton), International Journal of Science and Research (IJSR). 2016:5(4):1975-9.

37. Sobha K, Poornima A, Harini P, Veeraiah K. A study on biochemical changes in the fresh water fish, Catla catla (Hamilton) exposed to the heavy metal toxican cadmium chloride. Kathmandu University Journal of Science, Engineering and Technology. 2007:1(4):1-11.

38. Reddy NM, Ghousia B, Rajender K, Rao JV. Toxic impact of two organophosphate insecticides on biochemical parameters of a food fish and assessment of recovery response. Toxicology and Industrial Health. 2011;1-10

\section{GRAPHICAL ABSTRACT}

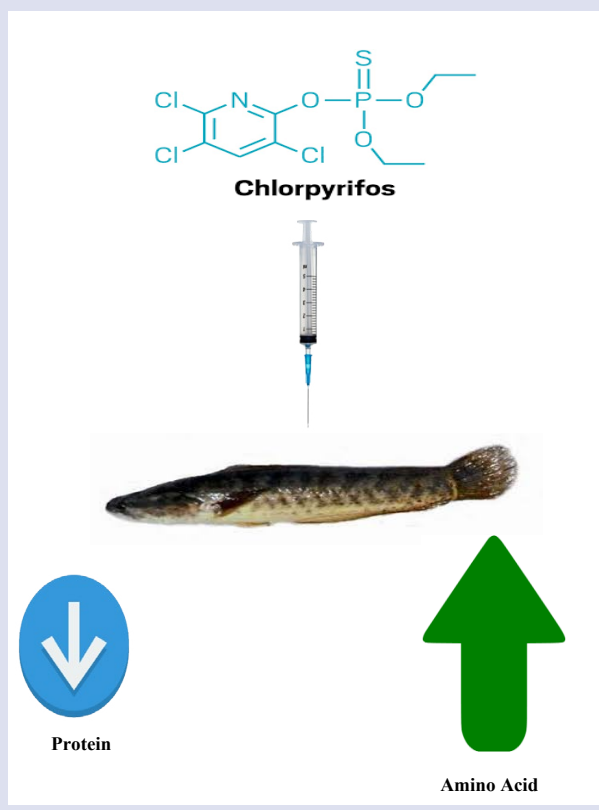




\section{ABOUT AUTHORS}

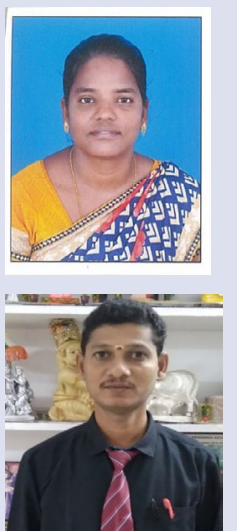

Revathi B Ph.D Research Scholar, Department of Zoology

Poompuhar College (Autonomous), Melaiyur-609 107. Sirkali Taluk, Nagapattinam. Tamilnadu, India.

Research Area: Fish Toxicology

She was joint Ph.D in Department of Zoology 2018. She got university rank holder in UG degree.

Dr. S. LAKSHMANAN Assistant Professor, Department of Zoology

Poompuhar College (Autonomous), Melaiyur-609 107. Sirkali Taluk, Nagapattinam. Tamilnadu, India. Specialization: Environmental Toxicology

$\mathrm{He}$ is the Corresponding author of this research paper. Total Teaching Experience on 10 years. He is guiding 2 Ph.D Scholars. Other informations are (1) Completed NCC Pre Commission Course From 14 December 2015 to 12 March 2016 at NCC Officers Training Academy, Kamptee, Nagpur. (2) Search and Rescue course at National Civil Defence College, Nagpur from 11.02.2016 to 12.02.2016. Number of Total Publications 12. In journals 10 and In Conferences 2.

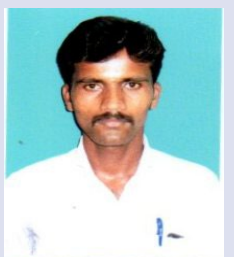

Veerakumar D Ph.D Research Scholar, Department of Zoology, Annamalai University, Annamalai Nagar- 608 002. Tamilnadu, India.

Research Area: Toxicology, Pharmacology

Google Scholar ID: Veerakumar Duraisamy

He joined Ph.D in Department of Zoology Annamalai university in 2015. Published research paper in journals 2. One is on Web of Science indexed Journal and another one is Elsevier indexed journal.

Cite this article: Revathi B, Lakshmanan S, Veerakumar D. Impact of Insecticide, Chlorpyrifos on Protein and Amino Acid Contents in Liver, Kidney and Brain of Exotic Teleost Fish, Channa punctatus (Bloch, 1973). Pharmacogn J. 2020;12(2):351-5. 